\title{
Impact of Financial Performance and Growth Opportunities on Success or Failure of Companies: Evidence from Tehran Stock Exchange
}

Chashmi NA* and Fadaee $\mathbf{M}$

Department of Accounting, Science and Research Branch, Islamic Azad University, Mazandaran, Iran

\begin{abstract}
In this study, has been investigated the impact of the financial performance and growth opportunities on success or failure of listed companies in The Tehran Stock Exchange. Measures of financial performance (including earnings per share, return on equity rate, and return on assets rate), also growth opportunities as the independent variables and success or failure as the dependent variable are considered. The main idea to formulate the hypothesis is that there is a significant relationship between the measures of discussed financial performance and growth opportunities and success or failure. Studied sample includes 115 listed companies in The Tehran Stock Exchange during the 7-years period (2006-2012). In order to analyze the data, were used Pearson correlation coefficient and multiple regressions. The results showed that there is significant relationship between earnings per share (EPS) and the rate of return on assets (ROA) with success or failure, but there is no significant relationship between rate of return on equity (ROE) and success or failure, and there is no significant relationship between growth opportunities and success or failure.
\end{abstract}

Keywords: Financial performance; Success or failure; Earnings per share; Return on assets rate; Return on equity rate; Growth opportunities

\section{Introduction}

Financial performance measurement has been discussed as a key priority in all economic decision making relating to public and private companies to identify the difficult locations and areas. Financial performance measurement is based on many decisions such as executive compensation, stock prices, stock risk, decisions related to investment, and many other cases. One of the main tasks of the managers is decision making, they should decide to plan, organizing and run. These decisions should be based on performance criteria and indicators in accordance with the organization's operations [1]. Continuous assessment of performance will cause to the emergence of timely and valuable documentary information for managers to decide with the aim of promoting organization and improving their activity. Understanding the important criteria for evaluating the performance and its indicators is useful for managers, investors, financial creditors such as banks. In order to address the goals of the organization performance measurement plays a crucial role. In addition corporate profitability always has been one of the main interest of stakeholders in companies. Corporate profitability in the future can be a very useful aid to their decision making in buying and selling stocks, also a warning to managers to improve their performance [1]. In any organization and business unit, there are collections of activities and factors that have a strong impact on the performance of the firm. So this collection should be evaluated for better performance of the firm. In today's competitive world, the only requirement for survival and participating in activities especially economic activity is accuracy and having efficiency. This will not be achieved unless with the planning, monitoring and ongoing evaluation of activities, because in this process that the capabilities and shortcomings are evident and can be treated before the occurrence of the event. According to the discussed matters, this question would be asked whether there is a significant relationship between the measures of financial performance and corporate success or failure.

The main objective of this study is to investigate the impact of financial performance and growth opportunities on corporate success or failure of listed companies in The Tehran Stock Exchange. The importance of this study is that it shows to managers, investors and other decision-makers, that there is a relationship between financial performance measures and success or failure, so that based on these results they can take more informed decisions. Investors in addition to the success or failure also can focus on financial performance, growth opportunities, measures in the companies and stock exchange according to the results can develop appropriate binding rules for the companies and their management. Based on existing theories, the conceptual framework of the present study can be demonstrated as below (Figure 1).

This means that the relationship between measures of financial

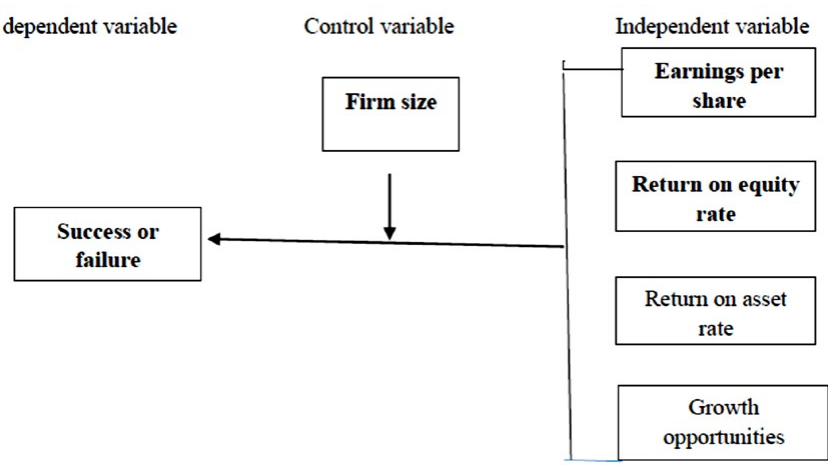

Figure 1: Conceptual framework of the study.

${ }^{*}$ Corresponding author: Chashmi NA, Department of Accounting, Science and Research Branch, Islamic Azad University, Mazandaran, Iran, Tel: +98 214486 5179; E-mail: narjes.ahmadian@gmail.com

Received March 02, 2016; Accepted March 24, 2016; Published March 29, 2016

Citation: Chashmi NA, Fadaee M (2016) Impact of Financial Performance and Growth Opportunities on Success or Failure of Companies: Evidence from Tehran Stock Exchange. J Account Mark 5: 166. doi:10.4172/2168-9601.1000166

Copyright: (c) 2016 Chashmi NA, et al. This is an open-access article distributed under the terms of the Creative Commons Attribution License, which permits unrestricted use, distribution, and reproduction in any medium, provided the original author and source are credited. 
performance and growth opportunities, and success or failure in above framework was discussable and according to the financial performance criteria can be useful for investors to make better decisions. In the following a summary of subject literature and discussed hypotheses is presented and then describe the variables used in the conceptual model. In the next parts, the research method, are presented statistical universe and sample and research findings are discussed and recommendations.

\section{Theoretical bases and overview on research literature}

In an enterprise whose aim is to increase the wealth of the owners, attention to the increase of profit provides requirements for realizing the objective. The calculation of financial performance dimension represents the achievement of organizational goals. Akmogo and Piski in their study concluded that proper investment in the training and employing experienced staff led to improve organizational performance and efficiency. Base and Mac Maurer research also have shown that proper investment in the training of staff is effective in financial performance [1]. Many studies have been made since long to achieve an appropriate measure for evaluating the performance of companies and directors to ensure alignment of corporate movement with the interests of potential investors and a basis for making economic decisions of potential investors and creditors [1]. Results obtained from these studies lead to present four approaches related to the performance criteria as follows:

Accounting approach: In this approach, the figures contained in financial statements, such as earnings, earnings per share, operating cash flows, return on assets, and return on equity are used for performance evaluation [2].

Economic approach: Under this approach, in which the economic concepts are used, performance of the business unit is assessed by emphasizing on the power of corporate assets' profitability and with regard to the return rate and used cost of capital rate [2]. Economic value added, adjusted economic value added and market value added are in this group.

Integrated approach: In this approach a combination of market and accounting data for performance evaluation, such as Tobin $Q$ ratio (Q Tobin) and price to earnings ratio is used [2].

Financial management approach: Under this approach, often is used from the theories of financial management, such as pricing pattern of capital assets and risk and return concepts. The main emphasis of this approach is to determine the excess return per share [2]. The impact of ownership structure on firm value based on the conflict of interests between share holders. Azadvar [3] believes that when the appropriate percentage of shares held by major shareholders, they can impose their policies on companies and to attract private interests. If not respected the rights of all share holders alike, increases the concentration of ownership in the hands of shareholders. Previous research has shown that major shareholders (controllers) against minority shareholders, have more control to improve the firm's performance on the managers. Also In accounting and finance, earnings before interest and taxes, a measure of profit that excludes interest expenses and taxes.

There are different theories on the relationship between profitability and capital structure. Azadvar [3] performed a study entitled the relationship between investment opportunities with the firm performance. The results and findings of the study indicate that according to the considered characteristics, there is positive relationship between investment opportunities and firm performance.
Azadvar [3] investigated the effect of ownership type on corporate performance in the Tehran Stock Exchange. The results of this study show although corporate performance improved after transfer, however statistically significant differences between corporate performance before and after the transfer are not found.

Bahramfa and Saei [4] studied the relationship between corporate investment on intellectual capital and business performance. His study showed significant relationship between intellectual capital and business performance of companies. His research results focus on this idea that investing resources in the acquisition of knowledge cause to increase firm value.

Hazak [5] to measure financial performance is used from the measure of return on assets rate. This criterion measures the amount of net profit against used assets.

Nissim [6] studied the relationship between managerial ownership and corporate performance of Small and Medium Private Companies in Germany. The research findings showed that performance of companies with managerial ownership percentage above $40 \%$ is improving. The purpose of growth opportunities, is the ratio of market value to book value of equity [6]. Teral et al. [7] examined the relationship between profitability and capital structure in Ghana who deals is positive with the relationship between profitability and capital structure suggests that its listed companies.

\section{Research Hypotheses}

$\mathbf{H}_{1:}$ There is a significant relationship between earnings per share and success or failure.

$\mathbf{H}_{2}$ : There is a significant relationship between return on equity rate and success or failure.

$\mathrm{H}_{3:}$ There is a significant relationship between return on asset rate and success or failure.

$\mathbf{H}_{4}$ : There is a significant relationship between growth opportunities and success or failure.

\section{Research model and its variables}

This study sought tries to investigate the impact of financial performance and growth opportunities on success or failure of companies listed in the Tehran Stock Exchange. The descriptive method is correlation type. This study is applied research and the Pearson correlation method and regression and also Eviews software will be used in data analysis. Research variables include independent variable, dependent variable and the control variable.

Financial performance: Performance evaluation measure is based on accounting models, especially accounting earnings or earnings per share model. Understanding the important criteria for evaluating the performance and its indicators is useful for managers and using them they can start to measure and evaluate the present situation of strategic plans of the organization [8] which is considered as independent variables in this study and include the following criteria.

Earnings per share: it is one of the key financial statistics that is of interest to investors and financial analysts and represents the profit that the company gained within a specified period for per ordinary share (Neveu, 2006). It is obtained by dividing the net profit after tax on the number of company shares.

Rate of return on equity: It is one of the financial ratios which is calculated through dividing profit before tax on equity [8]. This output 
indicates that how much return is created by investors about invested funds by them. This ratio is provided to show the profitability power of company toward book capital of shareholders [9].

Rate of return on assets: It is another accounting standard which shows the amount of management efficiency in applying existing resources for obtaining profit and is one of profitability ratios that source of profit is investigated not absolutely but also in connection with its acquisition source in its analysis [9]. This rate is obtained by dividing the net profit to total assets.

Growth opportunities: is achieved from the ratio of market value to book value of equity and to the study, this ratio is divided by total assets.

Success or failure: This variable means the success or failure of the company.

Firm size: To measure the firm size, we use the natural logarithm of net assets.

\section{Research Methodology}

The statistical universe of the present study is listed companies in Tehran Stock Exchange which is placed in the list of stock companies from 2006-2012. These samples consisted of companies that have the following characteristics:

1. They exist in the Tehran Stock Exchange before 2006.

2. Their activity did not change during fiscal years 2006-2012.

3. The end of their fiscal year is December 31 .

4. Their required data for doing the study is available.

5. They are not among investment or financial intermediation companies include insurance, banks and leasing. Because the nature and classification of the financial statements items of this group of companies are different from other companies.

Due to imposed restrictions and using Cochran Formula, 115 companies are selected as sample that the information related to it includes informational database and existing informational software (Rahavard Novin and Tadbir Pardaz software) and financial statements of the listed companies in Tehran Stock Exchange and also web sites (www.rdis.ir) and (www.irbours.ir).

\section{Findings and Data Analysis}

Descriptive statistics of the study which are shown in Table 1 include mean, median, maximum, minimum and standard deviation of research data. These amounts only present an overall overview of the distribution status of research data. Due to the proximity of the median and mean in most variables and also other statistics obtained from the different variables; we can conclude that all variables are distributed properly.

\section{Estimation of multivariate regression model}

As it is shown in Table 2, according to the obtained F statistics (16.701) can be expressed that at confidence levelof99 percent, on the whole financial performance and other independent variables have a relationship with Success or failure. The results also confirm this issue that approximately $9 \%$ of Success or failure changes are explained by the independent variables of the research.

Adjusted coefficient of determination for this model is $84 \%$ and means that $84 \%$ of the changes in dependent variable are explained by changes in the independent variable. Durbin Watson statistic also is used to investigate autocorrelation of the error terms of regression model. Whatever this statistics is closer to the number 2 shows absence of autocorrelation. In this study, then we can is mention that there is no autocorrelation between variables. Also according to the results in Table 2 it can be expressed that hypotheses number 1 and 3 are approved at the 99\% level and represents a significant relationship between earnings per share and the rate of return on assets with Success or failure and hypothesis number 2 and 4 at the $90 \%$ level are not approved (i.e. there are no significant relationship between the rate of return on equity and growth opportunities and success or failure).

\section{Test results of research hypotheses}

The first hypothesis testing: The purpose of formulating the first hypothesis is to investigating the relationship between earning per share and success or failure. According to the results obtained in Table 2 from estimating the model, coefficient of percentage of EPS variable is equal to $0 / 003$ and according to its $p$-value which is equal to $0 / 000$ and less than error level $0 / 1$. Consequently this hypothesis is confirmed at the $0 / 90$ confidence level.

The second hypothesis testing: The purpose of formulating the first hypothesis is to investigating the relationship between return on equity rate and success or failure. According to the results obtained in Table 2 from estimating the model, coefficient of percentage of ROE variable is equal to $0 / 020$ and according to its $p$-value which is equal to $0 / 467$ and greater than error level $0 / 1$. Consequently this hypothesis is not confirmed at the $0 / 90$ confidence level.

The third hypothesis testing: The purpose of formulating the first hypothesis is to investigating the relationship between return on asset rate and success or failure. According to the results obtained in Table 2 from estimating the model, coefficient of percentage of ROA variable is equal to $0 / 499$ and according to its p-value which is equal to $0 / 000$ and less than error level $0 / 1$. Consequently this hypothesis is confirmed at the $0 / 90$ confidence level.

The fourth hypothesis testing: The purpose of formulating the first hypothesis is to investigating the relationship between growth opportunities and success or failure. According to the results obtained in Table 2 from estimating the model, coefficient of percentage of GRO variable is equal to $0 / 125$ and according to its p-value which is equal to $0 / 080$ and greater than error level $0 / 1$. Consequently this hypothesis is not confirmed at the 0/90 confidence level. According to the Table 2, control variable of firm size has no a significant relationship with success or failure.

\begin{tabular}{|c|c|c|c|c|c|}
\hline Variables & Mean & Median & Maximum & Minimum & $0 / 0000$ \\
\hline Success or failure & $0 / 4108$ & $0 / 0000$ & $1 / 0000$ & $19 / 780$ \\
\hline Firm Size & 13,254 & 13,074 & $9 / 880$ & -16.100 \\
\hline Return on Equity & 0.361 & 0.380 & 10.040 & -0.340 \\
\hline Return on Assets & 0.107 & 0.090 & 0.640 & -21.410 \\
\hline Earnings Per Share & 5.728 & 1.400 & 162.680 & 0.983 \\
\hline Growth opportunities & $1 / 6699$ & $1 / 3288$ & $9 / 4251$ & $0 / 1092$ \\
\hline
\end{tabular}

Table 1: Descriptive statistics of variables. 
Citation: Chashmi NA, Fadaee M (2016) Impact of Financial Performance and Growth Opportunities on Success or Failure of Companies: Evidence from Tehran Stock Exchange. J Account Mark 5: 166. doi:10.4172/2168-9601.1000166

\begin{tabular}{|c|c|c|c|}
\hline Variables & Coefficient & t-Statistic & Sig. \\
\hline Constant & -0.465 & -5.364 & 0.000 \\
\hline SIZE & 0.0345 & 0.6235 & 0.5329 \\
\hline ROE & -0.020 & -0.727 & 0.467 \\
\hline ROA & 0.499 & 5.225 & 0.000 \\
\hline EPS & -0.003 & -3.677 & 0.000 \\
\hline Gro & 0.125 & 1.746 & 0.080 \\
\hline$R^{2}$ & & 0.089 & \\
\hline Adjusted R & & 0.084 & \\
\hline F-statistic & & 16.701 & \\
\hline Sig (F-statistic) & \multicolumn{3}{|c}{0.000} \\
\hline Durbin Watson & \multicolumn{3}{|c}{} \\
\hline & Table 2: Estimation results of the model. \\
\hline
\end{tabular}

\section{Conclusions}

The results of testing hypotheses according to information of existing companies in the Tehran Stock Exchange during fiscal years 2006-2012 show that there is significant relationship between financial performance and corporate Success or failure.

In this study, it has not been observed the relationship between the rate of return on equity (ROE) as a measure of financial performance and Success or failure; therefore, policymakers should note that the rate of return on equity (ROE) is not appropriate criteria for determining necessary policy for Success or failure. And it is recommended that pay attention to the other financial performance measures such as economic value added, retained earnings, cash flows and so on. Also it has been observed that the company's financial performance based on the rate of return on assets (ROA) and earnings per share (EPS) will affect Success or failure.

According to research findings also suggest that investors during making decisions study financial statements and reporting of companies and also consider factors such as firm size, financial leverage, earnings per share and industry type. In this research has also shown that the size of listed companies in Tehran Stock Exchange has a no impact on their Success or failure. And profitability has a significant impact on success or failure of company

\section{References}

1. Azarbaijani K, Soroushyar A, Kopaei YS (2011) Find the best measure of financial performance.

2. Ansari AM, Karimi M (2008) Investigation financial measures of Management Performance Assessment in value creation for shareholders with an emphasis on economic measures.

3. Azadvar I (2007) Relationship between investment opportunities with the company's performance.MA Thesis of Accounting.

4. Bahramfa N, Saei MJ (2006) Provide a model to predict financial performance of listed companies in The Tehran Stock Exchange. Journal of Accounting and Auditing Review.

5. Hazak A (2007) Dividend Decision under distributed profit taxation: investor's perspective. International Research Journal of Finance and Economics.

6. Nissim D, Oziv A (2001) Dividend changes and future profitability. Journal of Finance 56: 6.

7. Teral A, Lukason O, Sander P (2013) The Influence of Financial Performance on Payout Policy: A Study of Estonian Firms. Social Science Research Network.

8. Vakilifard HR (2011) Decision-making in Financial Issues. Financia Management, Jangal Publication, Tehran.

9. Weigand RA, Baker KH (2009) Changing perspectives on distribution policy: The evolution from dividends to share repurchase. Managerial Finance 35: 479-492. 